\title{
Febuxostat as an alternative therapy in COVID-19: A double-blind randomized clinical trial
}

\author{
Lotfollah Davoodi $^{1}$, Seyed Mohammad Abedi ${ }^{1}$, Ebrahim Salehifar ${ }^{2}$, Reza Alizadeh-Navai ${ }^{1}$, \\ Hamed Rouhanizadeh ${ }^{1}$, Ghasemali Khorasani ${ }^{3}$, and Seyed Jalal Hosseinimehr ${ }^{2}$ \\ ${ }^{1}$ Mazandaran University of Medical Sciences Faculty of Medicine \\ ${ }^{2}$ Mazandaran University of Medical Sciences Faculty of Pharmacy \\ ${ }^{3}$ Tehran University of Medical Sciences School of Medicine
}

May 21, 2020

\begin{abstract}
Aims: The aim of this double-blind randomized clinical trial was to determine the effects of FBX in comparison with hydroxychloroquine (HCQ) on clinical symptoms, laboratory tests and chest CT findings in patients with COVID-19-causing moderate symptomatic disease. Methods: We conducted a randomized, double blind clinical trial involving adult outpatients' patients with COVID-19 infection, which causes the moderate respiratory illness. Sixty patients were randomly assigned to receive either FBX or HCQ for 5 days. The measured variables were clinical and laboratory data including rate of fever, cough, berating rate, C-Reactive Protein level, lymphocytes count at onset of admission and was well as at 5 days of treatments. In addition, CT lesions were evaluated on admission and 14 days of treatments in both groups. Results: Fever, cough and tachypnea significantly mitigated in both groups after five days of treatments. The lymphocytes count significantly increased in both treatment groups and the CRP values were dropped in normal range (negative) in major of patients receiving FBX or HCQ treatment. It was not observed any significantly difference between FBX and HCQ in frequency of these symptoms. The mean percentages of CT abnormality scores were significantly reduced to $7.3 \%$ and $8 \%$ after 14 days of FBX and HCQ treatments, respectively. In adult outpatients with moderate symptomatic Covid-19, the effectiveness of FBX was same to HCQ in improvement of clinical manifestations, laboratory tests and CT lesions. Conclusion: These findings suggest FBX as an alternative treatment for Covid-19 infection in patients with contraindication or precaution to HCQ.
\end{abstract}

\section{Introduction}

Coronavirus (Covid-19)-caused respiratory tract illness may result to severe progressive pneumonia, multiorgan failure and death in critically ill patients $[1,2]$. There is no specific antiviral treatment against covod-19 infection but some antiviral drugs have been used as empirical [3]. The treatments are usually symptomatic and supportive. Severe patients with coronavirus disease had lower lymphocytes counts, higher leukocytes count and lower percentages of monocytes, eosinophils, and basophils. Elevation in inflammatory cytokines including IL-2R, IL-6, IL-8, IL-10, and TNF- $\alpha$. IL-6 and dysregulation of immune system were observed [4]. The expression levels of interleukin-2 receptor (IL-2R) and IL-6 in the serum were associated with severity of coronavirus diseases when were analyzed among critical, severe and mild groups. s [5]. In addition, virus infection causes NF-kB over expression that has a central role in massive overproduction of pro-inflammatory cytokines as well as triggering a variety of cellular responses, including cell phagocytosis, maturation of dendritic cells, and chemotaxis of cells [6]. The uncontrolled inflammatory response may result in pulmonary tissue damage, functional impairment, and reduced lung capacity. Hence, scientists believe that an excessive production of IL-6 is acted as a key role of chronic inflammation and is associated with severe lung damage

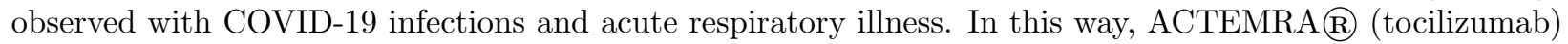
as an anti-IL-6R MAb binds to both the membrane-bound and soluble forms of IL-6R and rapidly depletes 
circulating levels of IL-6 in the blood. It is a FDA-approved anti-interleukin (IL)-6 receptor therapy for rheumatoid arthritis [7]. Febuxostat (FBX) is a novel non-purine xanthine oxidase (XO)-specific inhibitor that is used for treating hyperuricemia in patients with gout. FBX by inhibiting oxidation, reduces the inflammation stress [8]. Several studies have already demonstrated the anti-inflammatory [9], anti-oxidant [10] and anti-apoptosis effects of FBX [11]. Several preclinical studies showed that FBX therapy can remarkably inhibit inflammatory responses through reducing the levels of pro-inflammatory cytokines such as tumor necrosis factor (TNF)- $\alpha$, interleukin (IL)-1 $\beta$, IL-6 as well as decreasing the nuclear factor kappa B $(\mathrm{NF}-\varkappa \mathrm{B})$ as a key regulator of inflammation [12-14]. Several studies have shown FBX markedly protects animal against toxic-induced lung inflammation through downstream inflammatory mediators and oxidative stress [15-17]. FBX markedly accelerates pulmonary endothelial barrier recovery and improves survival in lipopolysaccharide-induced murine sepsis [18]. This double-blind randomized clinical trial was conducted to assess the effects of FBX and hydroxychloroquine (HCQ) on clinical symptoms, laboratory tests and chest CT findings of patients with COVID-19 infection.

\section{Material}

\subsection{Study Design}

A randomized, double-blind clinical trial, recruited patients from March 16, 2020, to April 10, 2020, at Mostafavian Fever Clinic in Sari (Iran). Sixty patients who had inclusion criteria entered into the study after the goals of the study were explained to them. This study was approved by the Ethical and Research Committee of Mazandaran University of Medical Sciences (ID\#7294) and was registered with Ethical number as IR.MAZUMS.REC.1398.7294. This study was submitted and approved by the Iranian Registry of Clinical Trials with the IRCT number: IRCT2019072704434N1 (the full trial protocol can be accessed at: http://www.irct.ir). The study was performed in accordance with declaration of Helsinki. All patients signed the informed consent form. The study was a randomized double-blind clinical trial. Patients were randomized using the balance block method. Boxes were numbered (1 to 60) and divided into two groups; HCQ (30 patients) and FBX (30 patients). HCQ subjects were taken one tablet of HCQ $200 \mathrm{mg}$ twice daily (Amin Pharmaceutical Company, Iran) and the FBX group received one tablet of FBX 80 mg per day (Jalinus Pharmaceutical Company, Iran). The treatment duration was five days. Both patients and physician did not know the contents of tables. All patients were taken acetaminophen $325 \mathrm{mg}$, as needed, for controlling the fever. Sample size were determined 30 patients in both group based on $\mathrm{p} 1=0.9, \mathrm{p} 2=0.6$, $\mathrm{a}=0.05$ and $\mathrm{b}=0.2$ by related sample size formula.

\subsection{Inclusion Criteria}

The inclusions criteria include: 1; CT scan suggestive of lung's parenchymal involvement, 2; any symptoms of respiratory tract involvement include cough, dyspnea or tachypnea and history of COVID-19 patients contacting 3; Creatinine clearance greater than $60 \mathrm{ml} / \mathrm{min}$.

\subsection{Exclusion Criteria}

Suspicious patients for COVID-19 pneumonia, who had severe underlying diseases such as cardiovascular, lung and kidney diseases, sever pneumonia that needs hospitalization, unable to taken oral medication and patients using azathioprine, didanosine, mercaptopurine or pegloticase (due to drug interaction with FBX) exclude from the study.

\subsection{Outcome measures}

Patients were assessed for temperature, number of breathing per minute, cough, dyspnea, CRP, WBC and lymphocyte counts at onset of admission and $5^{\text {th }}$ day of treatment. In addition, the lung CT scans were evaluated at first and 14 days after the onset of treatment.

\subsection{Statistical analysis}

Normality of data was checked with Shapiro-Wilk Test. Independent sample t-test and Mann-Whitney $\mathrm{U}$ test (comparison of continuous variables between two groups), Wilcoxon matched-pair signed-rank test 
(comparison of continuous variables before and after treatment), and $\mathrm{Chi}^{2}$ test (comparing the qualitative data) were used for analysis. The method of analysis was intention-to-treat. The SPSS software version 21.0 (SPSS, Inc., Chicago, IL) was applied for statistical analysis.

\section{Results}

\subsection{Patients}

A total of sixty subjects were enrolled in this study including FBX group $(\mathrm{N}=30)$ and HCQ group $(\mathrm{N}=$ 30) (Figure 1). Six patients (1patients in FBX group and 5 patients in HCQ group) were excluded, because patients had indisposition in this study after 1 day or did not interest in follow-up (Figure 1). Six patients were hospitalized with presented features in in the next result subtitle. Table 1 shows baseline demographic and clinical characteristics of the 54 patients who enrolled in this study. The mean age of patients was 57.7 \pm 8.4 years, and $59 \%$ of the patients were men. Among these patients, the most common symptom was fever, followed by cough and shortness of breath. On admission, fever as temperature [?]37.8 (66.7\%), cough (87\%), higher breathing rate $>20(44.4 \%)$, dyspnea (35\%), positive CRP $(94.4 \%)$, lung injury with CT involvement $(100 \%)$ were found in enrolled patients. The WBC counts were $4578+-1539$. On admission, lymphopenia (lymphocytes count $<1500 / \mathrm{microL}$ ) was found in $44(81.5 \%)$ of patients. On admission, most patients had a mild to moderate pneumonia as documented by clinical manifestations and CT findings. There were not between-group differences in demographic characteristics baseline laboratory test results (e.g., CRP, WBC and lymphocytes counts) and CT scores for lung lesions (Table 1).

\subsection{Primary outcome}

Patients were re-evaluated at five days after admission, when they took FBX or HCQ, as ordered. The sign/symptoms of fever, cough and higher breathing rate significantly mitigated in patients treated with FBX or HCQ (Table 2) after five days of treatment in both groups $(P<0.01)$. It was not observed any significantly difference between FBX and HCQ in frequency of these symptoms. The lymphocytes count significantly increased in both treatment groups after 5 days. The mean lymphocytes counts were $1308+-$ 617 and $1258+-498$ for FBX and HCQ groups at first days of admission whereas they were increased to 1962 +- 478 and 1911 +- 798 after 5 days with FBX and HCQ treatments, respectively. No significant differences were observed between FEB and HCQ in lymphocytes counts. The CRP values were dropped in normal range (negative) in most of patients after receiving FBX or HCQ treatment. FBX and HCQ treatments showed insignificant difference in the percentages of negative CRP values after 5 days after treatments.

\subsection{Secondary outcome}

As all patients infected with COVID-19 had chest CT abnormality, symptoms or changes on chest CT scans was monitored for COVID-19 progression or mitigation. The lung injuries were evaluated after 14 days of first admission in patients. The CT abnormalities were $16 \%$ and $19.2 \%$ in FBX and HCQ groups at first of admission, while these scores significantly reduced to $7.3 \%$ and $8 \%$ after 14 days, respectively, in which efficacies of reduction were $47.4 \%$ and $58.3 \%$ as compared to first admission $(P=0.004$ and $<0.001$, respectively).

\subsection{Hospitalization and mortality}

Six patients (11\%) were hospitalized because of increased symptoms (3 patients in FBX group and 3 patients in HCQ group). The hospitalization rates of patients were nearly the same in both groups. These patients were taken 2-5 days of FBX or HCQ treatments. All of hospitalized patients were released from hospitals between 1 to 7 days of hospitalization. It was not observed any mortality and no patients needed to admit in intensive care unit (ICU).

\section{Discussion}

This randomized clinical trial found that FBX treatment showed equal effectiveness with HCQ in improvement of clinical manifestations and para-clinical abnormalities after 5 days' administration in outpatients with COVID-19. It is notable that none of patients took antiviral medicine in this study, whereas patients 
received only FBX or HCQ in combination with acetaminophen (as needed order for fever). Six patients including 3 out of 29 (10\%) patients in FBX group and 3 out of $25(12 \%)$ patients in HCQ were admitted to hospital because of progressing symptoms, but none needed ICU admission, a totally $11 \%$ of study patients needed to be hospitalized. In China, 15-20\% of cases required hospitalization, with around $15 \%$ severe and $5 \%$ requiring ICU [19]. In Italy, approximately $40 \%$ of patients have been hospitalized, whereas nearly $7 \%$ admitted to ICU [20]. There is significant variation in the rate of hospitalization of patients with COVID-19 in the world. However, sample size of our clinical trial was smaller than these studies, in addition patients with significant comorbidities such as sever cardiovascular and renal diseases were excluded in our clinical trial. Clinical symptoms such as fever, cough and shortness of breath were observed in a large proportion of patients at admission, but these manifestations markedly reduced or resolved (e.g., fever and dyspnea) after 5 days of using FBX or HCQ. It was not observed any statistically difference in mitigating of clinical symptoms between FBX and HCQ treatments. In a systematic review included 656 patients (from 58 articles), fever $(88.7 \%)$, cough $(57.6 \%)$ and dyspnea $(45.6 \%)$ were the most prevalent manifestations [21].

Blood lymphocyte count has shown one of the most significant and consistent trend, suggesting that this indicator might reflect the disease progression, and lymphopenia is a predictor of prognosis in COVID-19 patients [22]. Lymphopenia (lymphocytes $<1500$ per $\mathrm{mm}^{3}$ ) is the most common lab finding in COVID-19 and is found in as many as $80 \%$ of the nonsevere patients on admission. Most of the patients had elevated levels of CRP $(56 \%)$. Patients with severe disease had more prominent laboratory abnormalities (including lymphopenia and elevated CRP) than those with nonsevere disease [23]. Lymphopenia was observed in $81.5 \%$ of patients [FBX (79.3\%) and HCQ (84\%), $\mathrm{P}=0.66$ ] at onset of admission, while lymphocyte counts significantly increased after 5 days of treatments to normal range, and lymphopenia was observed on $28.6 \%$ and $30.4 \%$ of patients in FBX and HCQ treatment after 5 days, respectively $(P<0.002)$. It is shown that both treatments significantly improved lymphocyte counts during 5 days of treatments. At 5 days of treatment, the mean of lymphocyte count in FBX was greater than HCQ; however, it was statistically non-significant $(P=0.88)$. Elevated CRP as positive CRP was observed in $96.6 \%$ patients [FBX $(96.6 \%)$ and HCQ (92\%), $P=0.47$ ] at onset of admission, while FBX and HCQ significantly reduced after 5 days of treatment to negative range to $50 \%(P<0.001)$ and to $40 \%(\mathrm{P}=0.03)$ of patients, respectively; however, there was no statistically significant difference between two group in CRP's response to treatment after 5 days $(P=0.49)$.

Chest CT images from patients with COVID-19 typically demonstrate bilateral, peripheral ground glass opacities. In China report, of $975 \mathrm{CT}$ scans that were performed at the time of admission, $86.2 \%$ revealed abnormal results [23]. In our study, diagnosis was based on clinical symptoms, laboratory findings, history of COVID-19 patients contacting and lung CT abnormalities consistent with coronavirus pneumonia at early phase. Due to a high sensitivity of lung CT in detecting lung involvement and also the importance of initiating the treatment as soon as possible, we included patients who were COVID-19 infection. The real time Reverse Transcription Polymerase Chain Reaction (rRT-PCR) were not performed due to some limitation in our study. We believe that this limitation would not affect the validity of our results. High sensitivity of lung CT in diagnosis of COVID-19 infection was frequently reported in previous studies. For instance, Long et al, reported $97.2 \%$ sensitivity for CT whereas the sensitivity of initial rRT-PCR was only $83.3 \%$ and rRT-PCR may produce initial false negative results. Only one patient was observed with positive rRT-PCR but negative CT. Considering that the results of rRT-PCR may be false-negative, and the relatively long assay time, they suggested that patients with typical CT findings but negative rRT-PCR results should be isolated and rRT-PCR repeated to avoid misdiagnosis [24]. In our study, at admission all patients showed chest CT abnormalities (100\%), while FBX or HCQ treatments significantly cleared CT abnormalities in $31 \%$ and $32 \%$ of patients after 14 days of treatments, respectively. All data show that FBX is affective as HCQ in improvement of clinical symptoms and also laboratory and radiographic abnormalities in outpatients with COVI-19. No FDA-approved drug has demonstrated safety and efficacy in randomized controlled trials for patients with COVID-19. Multiple drugs within vitro antiviral activity against SARS-CoV-2 and/or immunomodulatory effects that have been suggested to be clinically beneficial. In our protocol, HCQ is prescribed in combination with acetaminophen for controlling fever. However, antiviral drug is sometimes added 
to this medicine protocol, there is challenge the effectiveness of available anti-viral medicine for management of Covid-19, then infectious specialist medical doctor has not prescribed antiviral medicine to patients in this study. Recent publication showed the in vitro activity of chloroquine (CQ) as known antimalarial drug against SARS-CoV-2. CQ effectively blocked virus infection at low micromolar concentration and showed high selectivity index. Several mechanism actions are suggested for CQ are including a widely-used antimalarial and autoimmune disease drug as well as anti-viral drug. CQ is known to block virus infection by increasing endosomal $\mathrm{pH}$ required for virus/cell fusion, as well as interfering with the glycosylation of cellular receptors of SARS-CoV-2 [25]. Several clinical studies were conducted in Chinese hospitals for use of CQ or HCQ in treatment of SARS-CoV-2-caused pneumonia. The first results obtained from more than 100 patients showed the superiority of CQ compared with treatment of the control group in terms of reduction of exacerbation of pneumonia, duration of symptoms and delay of viral clearance, without severe side effects. This has led in China to include CQ in the recommendations regarding the prevention and treatment of COVID-19 pneumonia. The anti-viral and anti-inflammatory activities of CQ may account for its efficacy in treating patients with COVID-19 pneumonia [26-28]. HCQ, as similar to CQ, increases the $\mathrm{pH}$ and confers anti-viral effects. As compared to CQ, HCQ has fewer side effects, better safety profile and less drug interactions [29]. A study has demonstrated that HCQ is more potent than CQ in inhibiting SARS-CoV-2 in vitro [30]. Gautret, et al, were the first to report promising in vivodata of HCQ in a non-randomized clinical trial in France. A total of 20 patients received HCQ and 16 were control patients who were analyzed. They used $200 \mathrm{mg}$ of HCQ three times a day for 10 days, plus azithromycin (AZM) if deemed necessary. A higher frequency of SARS-CoV-2 clearance was noticed after 6 days of treatment with HCQ alone or HCQ+AZM versus the untreated control group $(70 \%$ vs $12.5 \% ; \mathrm{P}<0.001)$. In this study, $\mathrm{PCR}$ results in nasopharyngeal samples and clearing viral nasopharyngeal carriage of SARS-CoV-2 in COVID-19 patients were evaluated. None clinical symptoms, laboratory tests and lung CT features were reported in both groups of patients. Some limitations of this study were a small sample size and limited long-term outcome follow-up [31]. In other study, Gautret, et al studied an uncontrolled non-comparative observational study in a cohort of 80 relatively mildly infected inpatients treated with a combination of HCQ and AZT over a period of at least three days. Patients were prescribed a combination of $200 \mathrm{mg}$ of oral HCQ sulfate, three times per day for ten days combined with AZT. A rapid fall of nasopharyngeal viral load tested by qPCR was noted, with $83 \%$ negative at Day7, and $93 \%$ at Day 8 . The number of patients presumably contagious (with a PCR Ct value $<34$ ) steadily decreased overtime and reached zero on Day 12. A marked decrease was observed after six days of treatment. Only $15 \%$ required oxygen therapy during their stay in out infectious disease (ID) ward. Authors claimed that for all other patients in this cohort of 80 people, the combination of HCQ and AZT resulted in a clinical improvement that appeared superior when compared to outcomes of other hospitalized patients, as described in the literature. Authors concluded that they have provided evidence of a beneficial effect of co-administration of HCQ with AZT in the treatment of COVID-19 and its potential effectiveness in the early reduction of contagiousness [32]. On March 2020, medRxiv.org published data of the first completed randomized clinical trial in Wuhan investigating the efficacy of HCQ in patients with COVID-19. Sixty patients were randomized equally into two groups. The treatment group received oral HCQ $400 \mathrm{mg} / \mathrm{d}$ (200 mg/bid) from day 1 to 5 . Their article is currently under revision. The body temperature recovery time and the cough remission time were significantly shorter in the HCQ treatment group. Besides, a larger proportion of patients with improved pneumonia were in the HCQ treatment group $(80.6 \%, 25$ of 31 ) compared with the control group $(54.8 \%, 17$ of 31$)$. Notably, all four patients progressed to severe illness occurred in the control group. There were two patients with mild adverse reactions in the HCQ treatment group. Among patients with COVID-19, the use of HCQ could significantly shorten time to clinical recovery (TTCR) and promote the absorption of pneumonia [33, 34]. To date, despite some promising results associated to efficacy and safety of HCQ in COVID-19, the evidence regarding its effect remains limited [35]. Infrequent and rare side effects include retinal toxicity, cardiac toxicity, QT interval prolongation and agranulocytosis have been observed with HCQ and CQ in patients. Life threatening arrhythmias associated with CQ and HCQ appear to be rare but if these drugs were to be used much more extensively then caution and appropriate monitoring are necessary [36, 37]. Patients and their physicians prescribing HCQ need to be keenly aware of retinal toxicity risks and the importance of regular screening, and ophthalmologists who see 
these patients should keep retinal toxicity in the front of their minds [38-40]. However, chronic use of HCQ can result in an acquired lysosomal storage disorder, leading to a drug-induced cardiomyopathy characterized by concentric hypertrophy and conduction abnormalities associated with increased adverse clinical outcomes and mortality [41]. Considering the short time use of HCQ, these side effects are probably no critical in patients with COVID-19.

In addition, HCQ has immunomodulatory and anti-inflammatory effects [42-44], which may be beneficial in patients with Covid-19 who inflammatory response and storm cytokine production make damaged lung worse. HCQ interfere with lysosomal activity and autophagy, interact with membrane stability and alter signaling pathways and transcriptional activity, which can result in inhibition of cytokine production and modulation of certain co-stimulatory molecules [43]. The NF- $x \mathrm{~B}$ transcription factor has emerged as the central regulator of inflammatory processes. It achieves this status through numerous important pro-inflammatory factors under its transcriptional control. NF- $\chi \mathrm{B}$ plays a central role in inflammatory diseases such as rheumatoid arthritis, inflammatory bowel disease, and autoimmunity. NF- $x \mathrm{~B}$ is activated through microbial products and proinflammatory cytokines, as well as endogenous ligands that function as its trigger during tissue injury, the latter of which may promote inflammation in the absence of infection [45-47]. In addition, viral infections cause NF- $x \mathrm{~B}$ overexpression, which plays a crucial role in the production of pro-inflammatory cytokine storms and triggers various cellular responses, including cell phagocytosis, dendritic cell maturation, and chemotaxis [6]. NF- $\varkappa \mathrm{B}$ signaling is also a key regulator of lipopolysaccharide-induced pulmonary inflammation [48, 49]. There is strong crosstalk between NF- $\chi \mathrm{B}$ and cytokine activation and production, in which cytokines and proinflammatory mediators activate $\mathrm{NF}-\varkappa \mathrm{B}$, and $\mathrm{NF}-\chi \mathrm{B}$ also activates cytokine production. This cycle can enter an uncontrolled, positive feedback loop, resulting in the production of a cytokine storm. It is suggested that downregulation of NF- $x \mathrm{~B}$ results in the attenuation of inflammatory cytokine signaling. In addition, several pre-clinical studies have demonstrated the beneficial effects of NF- $\varkappa \mathrm{B}$-targeting inhibitors in the prevention and treatment of lung inflammation induced by toxic agents in preclinical models [49-55]. HCQ inhibits IL-6, TNF- $\alpha$, IL-1 $\beta$ and NF- $\chi \mathrm{B}$ [44, 56-58], also it inhibits the activation of NF- $\chi \mathrm{B}$ in the lung of bleomycintreated rats [59]. HCQ prevents the TNF-alpha-induced translocation of NF-kB p65 into the nucleus and the phosphorylation of the p65 subunit. HCQ administration also suppresses TNF-alpha induced lung injury in mice by reducing neutrophil infiltration in pulmonary interstitial tissue [60]. It seems that downregulation of $\mathrm{NF}-x \mathrm{~B}$ results in the attenuation of inflammatory cytokine signaling and may be a promising target for lung protection [61]. FBX is in a class of medications called xanthine oxidase (OX) inhibitors leading to decrease in uric acid production. Beside decreasing serum uric acid in gout by FBX, there are well documents that FBX suppresses pro-inflammatory cytokines such as IL-1 $\beta$, IL-6 MCP-1 and TNF- $\alpha$ as well as inhibits the oxidative stress and inflammatory responses through NF- $\chi \mathrm{B}$ pathway in animal models $[12,14,62,63]$. FBX is able to improve lung damage induced by toxic agents through down-regulation of oxidative stress pathway and suppression of inflammatory mediators $[10,18,64]$. In addition, FBX ameliorates histopathological changes in lung tissue [65]. There is not any report associated to anti-viral activity of FBX. Xanthine oxidase, which is responsible for the generation of oxygen free radicals, was elevated in serum and lung tissue of mice infected with influenza virus [66-68]. Due to the crucial roles of cytokines and pro-inflammatory mediators in severe acute respiratory syndrome induced by coronavirus 2 (SARS-CoV-2), with respect to beneficial effects of FBX in blockading the activation of cytokines and NF- $x$ B pathway, this medicine seems an effective drug for the prevention and treatment of lung inflammation in patients with COVID-19 in same efficacy with HCQ. However, future studies are needed to find exact mechanism of FBX in treatment of COVID-19 infection. The adverse effects associated with FBX therapy include nausea, diarrhea, arthralgia, headache, increased hepatic serum enzyme levels, rash and heart-related problems. These side effects were not observed in this study, which may be due to short time consuming of FBX, also we excluded patients with cardiovascular and chronic kidney diseases. The limitation of our study was the absence of placebo group. Considering ethical issues, we designed this study without a placebo group due to the life-threatening nature of COVID-19 infection.

\section{Conclusion}

We have provided evidence of a beneficial effect of administration of FBX as the same efficacy with HCQ 
in the treatment of COVID-19. Based on this study, FBX is effective in the reduction of clinical symptoms, modifying laboratory tests and chest CT abnormalities in COVID-19 outpatients. Given the urgent manage of outpatients and reducing entrance of sever patients to hospital, it is necessary to manage this disease with effective, safe, low cost drugs such as FBX. Immunemodulatory and anti-inflammatory effects of FBX may be involved in mitigating the initiating of cytokines storm which results to prevent severe acute respiratory disease in patients with COVID-19.

\section{Acknowledgments}

This study was supported by a grant from Mazandaran University of Medical Science, Sari, Iran (ID\#7294). We thank all patients who participated in this trial and their families. We thank Adel Heidari for assistance in this project. We appreciated the health care personals who have given their lives in the care of patients with Covid-19.

\section{DATA AVAILABILITY STATEMENT}

The data that support the findings of this study are available on request from the corresponding author. The data are not publicly available due to privacy or ethical restrictions.

\section{Conflict of interest statement}

The authors declare no potential conflicts of interest with respect to authorship, and/or publication of this study.

\section{Contributors}

L.D. and S.J.H. were involved in the conception of the study and obtaining funding. L.D., S.M.A., E.S, R.A, H.R, G.K and S.J.H contributed to the study and intervention designs. L.D., S.M.A., E.S. and S.H.J. contributed to the data collection. E.S and S.J.H. contributed to data analysis. All authors contributed to drafting and revising manuscript.

\section{References}

1. Huang C, Wang Y, Li X, Ren L, Zhao J, Hu Y, Zhang L, Fan G, Xu J, Gu X, Cheng Z, Yu T, Xia J, Wei Y, Wu W, Xie X, Yin W, Li H, Liu M, Xiao Y, Gao H, Guo L, Xie J, Wang G, Jiang R, Gao Z, Jin Q, Wang J, Cao B. Clinical features of patients infected with 2019 novel coronavirus in Wuhan, China. Lancet (London, England) 2020; 395: 497-506.

2. Wang D, Hu B, Hu C, Zhu F, Liu X, Zhang J, Wang B, Xiang H, Cheng Z, Xiong Y, Zhao Y, Li Y, Wang X, Peng Z. Clinical Characteristics of 138 Hospitalized Patients With 2019 Novel Coronavirus-Infected Pneumonia in Wuhan, China. JAMA 2020.

3. Cascella M, Rajnik M, Cuomo A, Dulebohn SC, Di Napoli R. Features, Evaluation and Treatment Coronavirus (COVID-19). In: StatPearls, Treasure Island (FL), 2020.

4. Qin C, Zhou L, Hu Z, Zhang S, Yang S, Tao Y, Xie C, Ma K, Shang K, Wang W, Tian DS. Dysregulation of immune response in patients with COVID-19 in Wuhan, China. Clin Infect Dis 2020.

5. Chen L, Liu HG, Liu W, Liu J, Liu K, Shang J, Deng Y, Wei S. [Analysis of clinical features of 29 patients with 2019 novel coronavirus pneumonia]. Zhonghua Jie He He Hu Xi Za Zhi 2020; 43: 203-08 (Abstract).

6. Li G, Fan Y, Lai Y, Han T, Li Z, Zhou P, Pan P, Wang W, Hu D, Liu X, Zhang Q, Wu J. Coronavirus infections and immune responses. J Med Virol 2020; 92: 424-32.

7. Tanaka T, Narazaki M, Kishimoto T. IL-6 in inflammation, immunity, and disease. Cold Spring Harbor perspectives in biology 2014; 6: a016295.

8. Sabán-Ruiz J, Alonso-Pacho A, Fabregate-Fuente M, Gonzalez-Quevedo CdlP. Xanthine oxidase inhibitor febuxostat as a novel agent postulated to act against vascular inflammation. Anti-Inflammatory \& Anti- 
Allergy Agents in Medicinal Chemistry (Formerly Current Medicinal Chemistry-Anti-Inflammatory and Anti-Allergy Agents) 2013; 12: 94-99.

9. Kataoka H, Yang K, Rock KL. The xanthine oxidase inhibitor Febuxostat reduces tissue uric acid content and inhibits injury-induced inflammation in the liver and lung. European journal of pharmacology 2015; 746: 174-79.

10. Ahmed MA, El Morsy EM, Ahmed AA. Protective effects of febuxostat against paraquat-induced lung toxicity in rats: Impact on RAGE/PI3K/Akt pathway and downstream inflammatory cascades. Life sciences 2019; 221: 56-64.

11. Wang S, Li Y, Song X, Wang X, Zhao C, Chen A, Yang P. Febuxostat pretreatment attenuates myocardial ischemia/reperfusion injury via mitochondrial apoptosis. Journal of translational medicine 2015; 13: 209.

12. Amirshahrokhi K. Febuxostat attenuates ulcerative colitis by the inhibition of NF-kappaB, proinflammatory cytokines, and oxidative stress in mice. Int Immunopharmacol 2019; 76: 105884.

13. Hao G, Duan W, Sun J, Liu J, Peng B. Effects of febuxostat on serum cytokines IL-1, IL-4, IL-6, IL-8, TNF-alpha and COX-2. Exp Ther Med 2019; 17: 812-16.

14. Khan SI, Malhotra RK, Rani N, Sahu AK, Tomar A, Garg S, Nag TC, Ray R, Ojha S, Arya DS, Bhatia J. Febuxostat Modulates MAPK/NF-kappaBp65/TNF-alpha Signaling in Cardiac Ischemia-Reperfusion Injury. Oxid Med Cell Longev 2017; 2017: 8095825.

15. Ahmed MAE, El Morsy EM, Ahmed AAE. Protective effects of febuxostat against paraquat-induced lung toxicity in rats: Impact on RAGE/PI3K/Akt pathway and downstream inflammatory cascades. Life Sci 2019; 221: 56-64.

16. Jacob S, Herndon DN, Hawkins HK, Enkhbaatar P, Cox RA. Xanthine oxidase contributes to sustained airway epithelial oxidative stress after scald burn. Int J Burns Trauma 2017; 7: 98-106.

17. Fahmi AN, Shehatou GS, Shebl AM, Salem HA. Febuxostat protects rats against lipopolysaccharideinduced lung inflammation in a dose-dependent manner. Naunyn Schmiedebergs Arch Pharmacol 2016; 389: 269-78.

18. Damarla M, Johnston LF, Liu G, Gao L, Wang L, Varela L, Kolb TM, Kim BS, Damico RL, Hassoun PM. XOR inhibition with febuxostat accelerates pulmonary endothelial barrier recovery and improves survival in lipopolysaccharide-induced murine sepsis. Physiol Rep 2017; 5.

19. Wu Z, McGoogan JM. Characteristics of and Important Lessons From the Coronavirus Disease 2019 (COVID-19) Outbreak in China: Summary of a Report of 72314 Cases From the Chinese Center for Disease Control and Prevention. JAMA 2020.

20. Lazzerini M, Putoto G. COVID-19 in Italy: momentous decisions and many uncertainties. Lancet Glob Health 2020.

21. Rodriguez-Morales AJ, Cardona-Ospina JA, Gutierrez-Ocampo E, Villamizar-Pena R, Holguin-Rivera Y, Escalera-Antezana JP, Alvarado-Arnez LE, Bonilla-Aldana DK, Franco-Paredes C, Henao-Martinez AF, Paniz-Mondolfi A, Lagos-Grisales GJ, Ramirez-Vallejo E, Suarez JA, Zambrano LI, Villamil-Gomez WE, Balbin-Ramon GJ, Rabaan AA, Harapan H, Dhama K, Nishiura H, Kataoka H, Ahmad T, Sah R, Latin American Network of Coronavirus Disease C-REahwlo. Clinical, laboratory and imaging features of COVID19: A systematic review and meta-analysis. Travel Med Infect Dis 2020: 101623.

22. Tan L, Wang Q, Zhang D, Ding J, Huang Q, Tang YQ, Wang Q, Miao H. Lymphopenia predicts disease severity of COVID-19: a descriptive and predictive study. Signal Transduct Target Ther 2020; 5: 33.

23. Guan WJ, Ni ZY, Hu Y, Liang WH, Ou CQ, He JX, Liu L, Shan H, Lei CL, Hui DSC, Du B, Li LJ, Zeng G, Yuen KY, Chen RC, Tang CL, Wang T, Chen PY, Xiang J, Li SY, Wang JL, Liang ZJ, Peng YX, Wei L, Liu Y, Hu YH, Peng P, Wang JM, Liu JY, Chen Z, Li G, Zheng ZJ, Qiu SQ, Luo J, Ye CJ, Zhu SY, 
Zhong NS, China Medical Treatment Expert Group for C. Clinical Characteristics of Coronavirus Disease 2019 in China. N Engl J Med 2020.

24. Xiong Z, Fu L, Zhou H, Liu JK, Wang AM, Huang Y, Huang X, Yi B, Wu J, Li CH, Quan J, Li M, Leng YS, Luo WJ, Hu CP, Liao WH. [Construction and evaluation of a novel diagnosis process for 2019-Corona Virus Disease]. Zhonghua yi xue za zhi 2020; 100: E019.

25. Wang M, Cao R, Zhang L, Yang X, Liu J, Xu M, Shi Z, Hu Z, Zhong W, Xiao G. Remdesivir and chloroquine effectively inhibit the recently emerged novel coronavirus (2019-nCoV) in vitro. Cell Res 2020; 30: 269-71.

26. Gao J, Tian Z, Yang X. Breakthrough: Chloroquine phosphate has shown apparent efficacy in treatment of COVID-19 associated pneumonia in clinical studies. Biosci Trends 2020; 14: 72-73.

27. multicenter collaboration group of Department of S, Technology of Guangdong P, Health Commission of Guangdong Province for chloroquine in the treatment of novel coronavirus p. [Expert consensus on chloroquine phosphate for the treatment of novel coronavirus pneumonia]. Zhonghua Jie He He Hu Xi Za Zhi 2020; 43: 185-88 (Abstract).

28. Colson P, Rolain JM, Lagier JC, Brouqui P, Raoult D. Chloroquine and hydroxychloroquine as available weapons to fight COVID-19. Int J Antimicrob Agents 2020: 105932.

29. Sahraei Z, Shabani M, Shokouhi S, Saffaei A. Aminoquinolines against coronavirus disease 2019 (COVID19): chloroquine or hydroxychloroquine. Int J Antimicrob Agents 2020: 105945.

30. Yao X, Ye F, Zhang M, Cui C, Huang B, Niu P, Liu X, Zhao L, Dong E, Song C, Zhan S, Lu R, Li H, Tan W, Liu D. In Vitro Antiviral Activity and Projection of Optimized Dosing Design of Hydroxychloroquine for the Treatment of Severe Acute Respiratory Syndrome Coronavirus 2 (SARS-CoV-2). Clin Infect Dis 2020.

31. Gautret P, Lagier JC, Parola P, Hoang VT, Meddeb L, Mailhe M, Doudier B, Courjon J, Giordanengo V, Vieira VE, Dupont HT, Honore S, Colson P, Chabriere E, La Scola B, Rolain JM, Brouqui P, Raoult D. Hydroxychloroquine and azithromycin as a treatment of COVID-19: results of an open-label non-randomized clinical trial. Int J Antimicrob Agents 2020: 105949.

32. Gautret P, Lagier JC, Parola P, Hoang VT, Meddeb L, Sevestre J, Mailhe M, Doudier B, Aubry C, Amrane S, Seng P, Hocquart M, Eldin C, Finance J, Vieira VE, Dupont HT, Honore S, Stein A, Million M, Colson P, La Scola B, Veit V, Jacquier A, Deharo JC, Drancourt M, Fournier PE, Rolain JM, Brouqui P, Raoult D. Clinical and microbiological effect of a combination of hydroxychloroquine and azithromycin in 80 COVID-19 patients with at least a six-day follow up: A pilot observational study. Travel Med Infect Dis 2020: 101663 .

33. reprint. m. https://doiorg/101101/2020032220040758 2020.

34. Alia E, Grant-Kels JM. Does Hydroxychloroquine Combat COVID-19? A Timeline of Evidence. J Am Acad Dermatol 2020.

35. Gbinigie K, Frie K. Should chloroquine and hydroxychloroquine be used to treat COVID-19? A rapid review. BJGP Open 2020.

36. Bauman JL, Tisdale JE. Chloroquine and Hydroxychloroquine in the Era of SARS - CoV2: Caution on Their Cardiac Toxicity. Pharmacotherapy 2020.

37. Bell JS, Bell JA, Creek DJ. Off-label prescribing in the midst of a pandemic: The case of hydroxychloroquine. Aust J Gen Pract 2020; 49.

38. Carter KL, Do DV. Hydroxychloroquine-induced Retinal Toxicity. J Rheumatol 2020; 47: 632.

39. Casado A, Lopez-de-Eguileta A, Fonseca S, Munoz P, Demetrio R, Gordo-Vega MA, Cervero A. Outer Nuclear Layer Damage for Detection of Early Retinal Toxicity of Hydroxychloroquine. Biomedicines 2020; 
8.

40. Dahrouj M, Young L. Hydroxychloroquine Retinopathy in the Era of Advanced Imaging Modalities. Int Ophthalmol Clin 2020; 60: 73-83.

41. Yogasundaram H, Putko BN, Tien J, Paterson DI, Cujec B, Ringrose J, Oudit GY. Hydroxychloroquineinduced cardiomyopathy: case report, pathophysiology, diagnosis, and treatment. Can J Cardiol 2014; 30: 1706-15.

42. Hu C, Lu L, Wan JP, Wen C. The Pharmacological Mechanisms and Therapeutic Activities of Hydroxychloroquine in Rheumatic and Related Diseases. Curr Med Chem 2017; 24: 2241-49.

43. Schrezenmeier E, Dorner T. Mechanisms of action of hydroxychloroquine and chloroquine: implications for rheumatology. Nat Rev Rheumatol 2020; 16: 155-66.

44. Muller-Calleja N, Manukyan D, Canisius A, Strand D, Lackner KJ. Hydroxychloroquine inhibits proinflammatory signalling pathways by targeting endosomal NADPH oxidase. Ann Rheum Dis 2017; 76: 891-97.

45. Baker RG, Hayden MS, Ghosh S. NF-kappaB, inflammation, and metabolic disease. Cell Metab 2011; 13: $11-22$.

46. Lawrence T. The nuclear factor NF-kappaB pathway in inflammation. Cold Spring Harbor perspectives in biology 2009; 1: a001651.

47. Pordanjani SM, Hosseinimehr SJ. The Role of NF-kB Inhibitors in Cell Response to Radiation. Curr Med Chem 2016; 23: 3951-63.

48. Jiang K, Guo S, Yang C, Yang J, Chen Y, Shaukat A, Zhao G, Wu H, Deng G. Barbaloin protects against lipopolysaccharide (LPS)-induced acute lung injury by inhibiting the ROS-mediated PI3K/AKT/NF-kappaB pathway. Int Immunopharmacol 2018; 64: 140-50.

49. Jin Y, Qian J, Ju X, Bao X, Li L, Zheng S, Chen X, Xiao Z, Chen X, Zhu W, Li W, Wu W, Liang G. Osthole Protects against Acute Lung Injury by Suppressing NF-kappaB-Dependent Inflammation. Mediators Inflamm 2018; 2018: 4934592.

50. El-Kholy AA, Elkablawy MA, El-Agamy DS. Lutein mitigates cyclophosphamide induced lung and liver injury via NF-kappaB/MAPK dependent mechanism. Biomed Pharmacother 2017; 92: 519-27.

51. Li W, Zhao R, Wang X, Liu F, Zhao J, Yao Q, Zhi W, He Z, Niu X. Nobiletin-Ameliorated Lipopolysaccharide-Induced Inflammation in Acute Lung Injury by Suppression of NF-kappaB Pathway In Vivo and Vitro. Inflammation 2018; 41: 996-1007.

52. Wan B, Xu WJ, Zhan P, Jin JJ, Xi GM, Chen MZ, Hu YB, Zhu SH, Liu HB, Wang XX, Zhang XW, Lv TF, Song Y. Topotecan alleviates ventilator-induced lung injury via NF-kappaB pathway inhibition. Cytokine 2018; 110: 381-88.

53. Wang J, Liu YT, Xiao L, Zhu L, Wang Q, Yan T. Anti-inflammatory effects of apigenin in lipopolysaccharide-induced inflammatory in acute lung injury by suppressing COX-2 and NF-kB pathway. Inflammation 2014; 37: 2085-90.

54. Zhao G, Wu H, Jiang K, Rui G, Zhu Z, Qiu C, Guo M, Deng G. IFN-tau inhibits S. aureus-induced inflammation by suppressing the activation of NF-kappaB and MAPKs in RAW 264.7 cells and mice with pneumonia. Int Immunopharmacol 2016; 35: 332-40.

55. Dai J, Gu L, Su Y, Wang Q, Zhao Y, Chen X, Deng H, Li W, Wang G, Li K. Inhibition of curcumin on influenza A virus infection and influenzal pneumonia via oxidative stress, TLR2/4, p38/JNK MAPK and NF-kappaB pathways. Int Immunopharmacol 2018; 54: 177-87. 
56. Zeidi M, Kim HJ, Werth VP. Increased Myeloid Dendritic Cells and TNF-alpha Expression Predicts Poor Response to Hydroxychloroquine in Cutaneous Lupus Erythematosus. The Journal of investigative dermatology 2019; 139: 324-32.

57. Sun Y, Zhang J, Li X, Sun E. [Hydroxychloroquine alleviates 5-fluorouracil-induced enteritis in mice and its mechanism]. Xi Bao Yu Fen Zi Mian Yi Xue Za Zhi 2020; 36: 1-8.

58. Silva JC, Mariz HA, Rocha LF, Jr., Oliveira PS, Dantas AT, Duarte AL, Pitta Ida R, Galdino SL, Pitta MG. Hydroxychloroquine decreases Th17-related cytokines in systemic lupus erythematosus and rheumatoid arthritis patients. Clinics (Sao Paulo) 2013; 68: 766-71.

59. Liu L, Ren J, He Z, Men K, Mao Y, Ye T, Chen H, Li L, Xu B, Wei Y, Wei X. Cholesterol-modified Hydroxychloroquine-loaded Nanocarriers in Bleomycin-induced Pulmonary Fibrosis. Scientific reports 2017; 7: 10737.

60. Li R, Lin H, Ye Y, Xiao Y, Xu S, Wang J, Wang C, Zou Y, Shi M, Liang L, Xu H. Attenuation of antimalarial agent hydroxychloroquine on TNF-alpha-induced endothelial inflammation. Int Immunopharmacol 2018; 63: 261-69.

61. Linard C, Marquette C, Mathieu J, Pennequin A, Clarençon D, Mathé D. Acute induction of inflammatory cytokine expression after $\gamma$-irradiation in the rat: effect of an $\mathrm{NF}-\varkappa \mathrm{B}$ inhibitor. International Journal of Radiation Oncology* Biology* Physics 2004; 58: 427-34.

62. Omori H, Kawada N, Inoue K, Ueda Y, Yamamoto R, Matsui I, Kaimori J, Takabatake Y, Moriyama $\mathrm{T}$, Isaka $\mathrm{Y}$. Use of xanthine oxidase inhibitor febuxostat inhibits renal interstitial inflammation and fibrosis in unilateral ureteral obstructive nephropathy. Clinical and experimental nephrology 2012; 16: 549-56.

63. Krishnamurthy B, Rani N, Bharti S, Golechha M, Bhatia J, Nag TC, Ray R, Arava S, Arya DS. Febuxostat ameliorates doxorubicin-induced cardiotoxicity in rats. Chem Biol Interact 2015; 237: 96-103.

64. Kataoka H, Yang K, Rock KL. The xanthine oxidase inhibitor Febuxostat reduces tissue uric acid content and inhibits injury-induced inflammation in the liver and lung. Eur J Pharmacol 2015; 746: 174-9.

65. Fahmi AN, Shehatou GS, Shebl AM, Salem HA. Febuxostat protects rats against lipopolysaccharideinduced lung inflammation in a dose-dependent manner. Naunyn-Schmiedeberg's archives of pharmacology 2016; 389: 269-78.

66. Oda T, Akaike T, Hamamoto T, Suzuki F, Hirano T, Maeda H. Oxygen radicals in influenza-induced pathogenesis and treatment with pyran polymer-conjugated SOD. Science 1989; 244: 974-6.

67. Ungheri D, Pisani C, Sanson G, Bertani A, Schioppacassi G, Delgado R, Sironi M, Ghezzi P. Protective effect of n-acetylcysteine in a model of influenza infection in mice. Int J Immunopathol Pharmacol 2000; 13: $123-28$.

68. Yokozawa T, Sekiya M, Cho EJ, Kurokawa M, Shiraki K. Effect of Wen-Pi-Tang extract on lung damage by influenza virus infection. Phytomedicine 2004; 11: 625-32.

Figure 1: CONSORT diagram, including the number of patients who started and continued trial treatment, and stopped.

Table 1. Demographic and clinical characteristics of the patients at Baseline

\begin{tabular}{lllll}
\hline Characteristic & Total $(\mathbf{N}=\mathbf{5 4})$ & Febuxostat $(\mathbf{N}$ & \multicolumn{2}{c}{ Hydroxychloroquine } \\
$\mathbf{( N = 2 5})$ & P-value \\
\hline Age (Mean \pm SD) & $57.7 \pm 8.4$ & $58 \pm 7.3$ & $57.3 \pm 9.7$ & 0.47 \\
Male sex; no (\%) & $32(59.3)$ & $16(55.2)$ & $16(64)$ & 0.51 \\
Current smoking; & $1(1.9)$ & $1(3.6)$ & $0(0)$ & 0.35 \\
no. $(\%)$ & & &
\end{tabular}




\begin{tabular}{|c|c|c|c|c|}
\hline Characteristic & Total $(\mathrm{N}=54)$ & $\begin{array}{l}\text { Febuxostat }(\mathrm{N} \\
=29)\end{array}$ & $\begin{array}{l}\text { Hydroxychloroquine } \\
(\mathrm{N}=25)\end{array}$ & P-value \\
\hline $\begin{array}{l}\text { Coexisting } \\
\text { conditions } \\
\text { Diabetes; no. (\%) } \\
\text { Lung disease; no. } \\
(\%)\end{array}$ & $15(27.8) 1(1.9)$ & $8(27.6) 0(0)$ & $7(28) 1(4)$ & 0.970 .28 \\
\hline $\begin{array}{l}\text { Fever }(\mathrm{T}>37.8 \\
\left.{ }^{\circ} \mathrm{C}\right)\end{array}$ & $36(66.7)$ & $16(55.2)$ & $20(80)$ & 0.054 \\
\hline $\begin{array}{l}\text { Body temperature; } \\
{ }^{\circ} \mathrm{C} \text { Mean } \\
\mathrm{SD} \\
\text { Median }\end{array}$ & 37.70 .4838 & $\begin{array}{lll}37.6 & 0.48 & 37.9\end{array}$ & 37.90 .4638 & 0.1 \\
\hline $\begin{array}{l}\text { Respiratory rate } \\
\text { Mean } \\
\text { SD } \\
\text { Median }\end{array}$ & 19.71 .819 & 19.81 .719 .5 & 19.61 .919 & 0.57 \\
\hline $\begin{array}{l}\text { Respiratory rate } \\
{[?] 20 / \mathrm{min} \text {; no. }} \\
(\%)\end{array}$ & $24(44.4)$ & $14(50)$ & $10(40)$ & 0.47 \\
\hline Cough; no. (\%) & $47(87 \%)$ & $27(93.1)$ & $20(80)$ & 0.15 \\
\hline Dyspnea; no. (\%) & $19(35.2 \%)$ & $10(35)$ & $9(36)$ & 0.9 \\
\hline $\begin{array}{l}\text { White Blood Cell } \\
\text { count Mean } \\
\text { SD } \\
\text { median }\end{array}$ & 457815394100 & 468917294300 & 444412994050 & 0.57 \\
\hline $\begin{array}{l}\text { Lymphocyte count } \\
\text { Mean } \\
\text { SD } \\
\text { median }\end{array}$ & 12855611195 & 13086171196 & 12584981194 & 0.75 \\
\hline $\begin{array}{l}\text { Lymphopenia }(< \\
1500 / \text { microL })\end{array}$ & $44(81.5)$ & $23(79.3)$ & $21(84)$ & 0.66 \\
\hline $\begin{array}{l}\text { CRP (positive); } \\
\text { no. }(\%)\end{array}$ & $51(94.4)$ & $28(96.6)$ & $23(92)$ & 0.47 \\
\hline $\begin{array}{l}\text { Lung CT } \\
\text { (\%involvement) } \\
\text { mean } \\
\text { SD } \\
\text { median }\end{array}$ & 17.59 .917 .5 & 166.520 & 19.212 .815 & 0.72 \\
\hline
\end{tabular}

Table 2. Outcomes in the febuxostat and hydroxychloroquine treatments

\begin{tabular}{|c|c|c|c|c|c|c|c|}
\hline $\begin{array}{r}\text { Febuxostat } \\
\text { Characteristi }(\mathrm{dN}=29)\end{array}$ & $\begin{array}{l}\text { Febuxostat } \\
(\mathrm{N}=29)\end{array}$ & $\begin{array}{l}\text { Febuxostat } \\
(\mathrm{N}=29)\end{array}$ & $\begin{array}{l}\text { Hydroxychl } \\
(\mathrm{N}=25)\end{array}$ & $\begin{array}{l}\text { ofbyquineych } \\
(\mathrm{N}=25)\end{array}$ & $\begin{array}{l}\text { lofbyqunimeychlc } \\
(\mathrm{N}=25)\end{array}$ & $\begin{array}{l}\text { P-value } \\
\text { (between } \\
\text { ogøqujise } \\
\text { Day 1) }\end{array}$ & $\begin{array}{l}\text { P-valu } \\
\text { (betw } \\
\text { group } \\
\text { Day } 5\end{array}$ \\
\hline Day 1 & Day 5 & $\begin{array}{l}\text { P-value } \\
\text { (within } \\
\text { group) }\end{array}$ & Day 1 & Day 5 & $\begin{array}{l}\text { P-value } \\
\text { (within } \\
\text { group) }\end{array}$ & & \\
\hline
\end{tabular}




\begin{tabular}{|c|c|c|c|c|c|c|c|c|}
\hline Characterist & $\begin{array}{l}\text { Febuxostat } \\
\mathrm{i}(\mathrm{dN}=29)\end{array}$ & $\begin{array}{l}\text { Febuxostat } \\
(\mathrm{N}=29)\end{array}$ & $\begin{array}{l}\text { Febuxostat } \\
(\mathrm{N}=29)\end{array}$ & $\begin{array}{l}\text { Hydroxych } \\
(\mathrm{N}=25)\end{array}$ & $\begin{array}{l}\text { ofbychimeych } \\
(\mathrm{N}=25)\end{array}$ & $\begin{array}{l}\text { ofbyadrioneych } \\
(\mathrm{N}=25)\end{array}$ & $\begin{array}{l}\text { P-value } \\
\text { (between } \\
\text { ogøqujise } \\
\text { Day 1) }\end{array}$ & $\begin{array}{l}\text { P-valu } \\
\text { (betwe } \\
\text { groups } \\
\text { Day 5) }\end{array}$ \\
\hline $\begin{array}{l}\text { Fever } \\
(\mathrm{T}> \\
37.8 \\
\left.{ }^{\circ} \mathrm{C}\right) ; \mathrm{n} \\
(\%)\end{array}$ & $\begin{array}{l}16 \\
(55.2)\end{array}$ & $0(0)$ & $\mathrm{NA}^{\zeta}$ & $20(80)$ & $0(0)$ & $\mathrm{NA}^{\zeta}$ & 0.054 & $\mathrm{NA}^{\zeta}$ \\
\hline $\begin{array}{l}\text { Body tem- } \\
\text { perature; } \\
{ }^{\circ} \mathrm{C} \text { Mean } \\
\text { SD } \\
\text { Median } \\
\text { Range }\end{array}$ & $\begin{array}{l}37.6 \quad 0.48 \\
37.9 \\
37-38.2\end{array}$ & $\begin{array}{l}37.10 .2737 \\
36.8-37.7\end{array}$ & 0.001 & $\begin{array}{l}37.90 .46 \\
3837-39\end{array}$ & $\begin{array}{l}370.2337 \\
36.7-37.7\end{array}$ & $<0.001$ & 0.1 & 0.1 \\
\hline $\begin{array}{l}\text { Respiratory } \\
\text { rate; Mean } \\
\text { SD } \\
\text { Median } \\
\text { Range }\end{array}$ & $\begin{array}{l}19.81 .719 \\
18-22\end{array}$ & $\begin{array}{l}17.32 .616 \\
16-26\end{array}$ & $<0.001$ & $\begin{array}{l}19.51 .85 \\
1918-24\end{array}$ & $\begin{array}{l}17.42 .416 \\
16-24\end{array}$ & 0.001 & 0.57 & 0.88 \\
\hline $\begin{array}{l}\text { Respiratory } \\
\text { rate } \\
{[?] 20 / \min ;} \\
\text { no. }(\%)\end{array}$ & $14(50)$ & $2(6.9)$ & $<0.001$ & $10(40)$ & $3(12)$ & 0.04 & 0.47 & 0.52 \\
\hline $\begin{array}{l}\text { Cough; } \\
\text { n }(\%)\end{array}$ & $\begin{array}{l}27 \\
(93.1)\end{array}$ & $\begin{array}{l}13 \\
(44.8)\end{array}$ & $<0.001$ & $20(80)$ & $\begin{array}{l}10 \\
(43.5)\end{array}$ & 0.008 & 0.15 & 0.92 \\
\hline $\begin{array}{l}\text { Dyspnea; } \\
\text { n }(\%)\end{array}$ & $\begin{array}{l}10 \\
(34.5)\end{array}$ & $3(10.7)$ & 0.07 & $9(36)$ & $4(17.4)$ & 0.06 & 0.9 & 0.49 \\
\hline $\begin{array}{l}\text { White- } \\
\text { cell } \\
\text { count; } \\
\text { mean } \pm \\
\text { SD }\end{array}$ & $\begin{array}{l}4689 \pm \\
1729\end{array}$ & $\begin{array}{l}6111 \pm \\
1511\end{array}$ & $<0.001$ & $\begin{array}{l}4444 \pm \\
1299\end{array}$ & $\begin{array}{l}6130 \pm \\
1421\end{array}$ & 0.001 & 0.57 & 0.96 \\
\hline $\begin{array}{l}\text { Lymphocyte } \\
\text { count; } \\
\text { mean } \pm \\
\text { SD }\end{array}$ & $\begin{array}{l}1308 \pm \\
617\end{array}$ & $\begin{array}{l}1962 \pm \\
748\end{array}$ & $<0.001$ & $\begin{array}{l}1258 \pm \\
498\end{array}$ & $\begin{array}{l}1911 \pm \\
798\end{array}$ & 0.002 & 0.75 & 0.82 \\
\hline $\begin{array}{l}\text { Lymphopenia } \\
(< \\
1500 / \text { mi- } \\
\text { croL }) \\
\text { Positive; } \\
\text { n }(\%)\end{array}$ & $\begin{array}{l}23 \\
(79.3)\end{array}$ & $8(28.6)$ & $<0.001$ & $21(84)$ & $7(30.4)$ & $<0.001$ & 0.66 & 0.88 \\
\hline $\begin{array}{l}\text { CRP } \\
\text { positive; } \\
\text { n }(\%)\end{array}$ & $\begin{array}{l}28 \\
(96.6)\end{array}$ & $14(50)$ & $<0.001$ & $23(92)$ & $12(60)$ & 0.03 & 0.47 & 0.49 \\
\hline
\end{tabular}




\begin{tabular}{|c|c|c|c|c|c|c|c|c|}
\hline \multicolumn{2}{|c|}{$\begin{array}{l}\text { Febuxostat } \\
\text { Characteristi }(\mathrm{dN}=29)\end{array}$} & \multirow{2}{*}{$\begin{array}{l}\begin{array}{l}\text { Febuxostat } \\
(\mathbf{N}=\mathbf{2 9})\end{array} \\
7.311 .75 \\
0-50^{\&}\end{array}$} & \multirow{2}{*}{$\begin{array}{l}\text { Febuxostat } \\
(\mathbf{N}=\mathbf{2 9}) \\
0.004\end{array}$} & \multicolumn{4}{|c|}{ 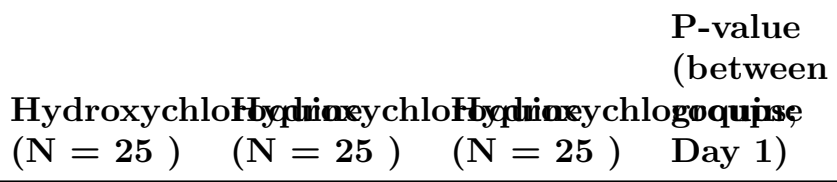 } & $\begin{array}{l}\text { P-valu } \\
\text { (betwe } \\
\text { group: } \\
\text { Day } 5\end{array}$ \\
\hline $\begin{array}{l}\text { Lung CT } \\
\text { (\% involve- } \\
\text { ment); } \\
\text { Mean } \\
\text { SD } \\
\text { Median } \\
\text { Range }\end{array}$ & $\begin{array}{l}166.520 \\
5-25\end{array}$ & & & $\begin{array}{l}19.212 .8 \\
155-50\end{array}$ & $\begin{array}{l}811.85 \\
0-50^{\&}\end{array}$ & $<0.001$ & 0.72 & 0.89 \\
\hline $\begin{array}{l}\text { Reduced } \\
\text { lung CT in- } \\
\text { volvement; } \\
\text { not } \\
\text { adjusted\&; } \\
\text { Mean } \\
\text { SD } \\
\text { Median } \\
\text { Range }\end{array}$ & $\begin{array}{l}-8.413-10 \\
-25 \text { to }+30 \\
\&\end{array}$ & $\begin{array}{l}-8.413-10 \\
-25 \text { to }+30 \\
\&\end{array}$ & $\begin{array}{l}-8.413-10 \\
-25 \text { to }+30 \\
\&\end{array}$ & $\begin{array}{l}-10.811 .4 \\
-10-45 \text { to } \\
+10^{\&}\end{array}$ & $\begin{array}{l}-10.811 .4 \\
-10-45 \text { to } \\
+10 \&\end{array}$ & $\begin{array}{l}-10.811 .4 \\
-10-45 \text { to } \\
+10 \&\end{array}$ & $0.86^{\#}$ & $0.86^{\#}$ \\
\hline $\begin{array}{l}\text { Reduced } \\
\text { lung CT in- } \\
\text { volvement; } \\
\text { adjusted }^{\&} \text {; } \\
\text { Mean } \\
\text { SD } \\
\text { Median } \\
\text { Range }\end{array}$ & $\begin{array}{l}47.49180 \\
-200 \text { to } \\
+100 \&\end{array}$ & $\begin{array}{l}47.49180 \\
-200 \text { to } \\
+100 \&\end{array}$ & $\begin{array}{l}47.49180 \\
-200 \text { to } \\
+100 \&\end{array}$ & $\begin{array}{l}58.36780 \\
-200 \text { to }+ \\
100 \&\end{array}$ & $\begin{array}{l}58.36780 \\
-200 \text { to }+ \\
100 \&\end{array}$ & $\begin{array}{l}58.36780 \\
-200 \text { to }+ \\
100 \&\end{array}$ & 1 & 1 \\
\hline $\begin{array}{l}\mathrm{CT} \\
\text { day14 } \\
\text { involve- } \\
\text { ment, } \\
\text { Nega- } \\
\text { tive; n } \\
(\%)\end{array}$ & 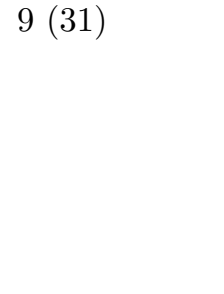 & $9(31)$ & $9(31)$ & $8(32)$ & $8(32)$ & $8(32)$ & 0.94 & 0.94 \\
\hline $\begin{array}{l}\text { Hospitalizatio } \\
\text { no. }(\%)\end{array}$ & n3 (10.3) & $3(10.3)$ & $3(10.3)$ & $3(12.5)$ & $3(12.5)$ & $3(12.5)$ & 0.81 & 0.81 \\
\hline
\end{tabular}

\&: indicate the Lung CT data on day 14; P-value indicates the difference of CT changes, Day 14 compared to Day 1 , for both row data and adjusted percent changes; $\mathrm{NA}^{\zeta}$ : not applicable 